\title{
Effects of maternal undernutrition during late pregnancy on the regulatory factors involved in growth and development in ovine fetal perirenal brown adipose tissue
}

\author{
Huan Yang ${ }^{1}$, Chi Ma ${ }^{1}$, Yang Zi ${ }^{1}$, Min Zhang ${ }^{1}$, Yingchun $\mathrm{Liu}^{2}$, Kaifeng $\mathrm{Wu}^{2}$, and Feng Gao ${ }^{1,3, *}$
}

\author{
* Corresponding Author: Feng Gao \\ Tel: +86-471-4309175, Fax: +86-471-4301530, \\ E-mail: oaa@imau.edu.cn \\ ${ }^{1}$ College of Animal Science, Inner Mongolia \\ Key Laboratory of animal nutrition and \\ feed, Inner Mongolia Agricultural University, \\ Hohhot, 010018, China \\ ${ }^{2}$ College of Life Science, Inner Mongolia \\ Key Laboratory of Biomanufacturing, Inner \\ Mongolia Agricultural University, Hohhot, \\ 010018, China \\ ${ }^{3}$ Key Laboratory of Mutton Sheep Genetics \\ and Breeding of Ministry of Agriculture \\ Hohhot, 010018, China \\ ORCID \\ Huan Yang \\ https://orcid.org/0000-0003-4222-9818 \\ Chi Ma \\ https://orcid.org/0000-0003-0547-7812 \\ Yang Zi \\ https://orcid.org/0000-0002-2154-2795 \\ Min Zhang \\ https://orcid.org/0000-0002-0686-0306 \\ Yingchun Liu \\ https://orcid.org/0000-0001-7719-3355 \\ Kaifeng Wu \\ https://orcid.org/0000-0002-3768-9898 \\ Feng Gao \\ https://orcid.org/0000-0002-4461-6611
}

Submitted Apr 25, 2021; Revised Jul 4, 2021; Accepted Aug 27, 2021
Objective: The experiment was conducted to evaluate the effects of maternal undernutrition during late pregnancy on the expressions of genes involved in growth and development in ovine fetal perirenal brown adipose tissue (BAT).

Methods: Eighteen ewes with singleton fetuses were allocated to three groups at day 90 of pregnancy: restricted group 1 (RG1, $0.33 \mathrm{MJ}$ metabolisable energy [ME]/kg body weight $\left.[\mathrm{BW}]^{0.75} / \mathrm{d}, \mathrm{n}=6\right)$, restricted group $2\left(\mathrm{RG} 2,0.18 \mathrm{MJ} \mathrm{ME} / \mathrm{kg} \mathrm{BW}^{0.75} / \mathrm{d}, \mathrm{n}=6\right)$, and a control group (CG, ad libitum, $0.67 \mathrm{MJ} \mathrm{ME} / \mathrm{kg} \mathrm{BW}^{0.75} / \mathrm{d}, \mathrm{n}=6$ ). The fetuses were removed at day 140 of pregnancy. All data were analyzed by using the analysis of variance procedure.

Results: The perirenal fat weight $(\mathrm{p}=0.0077)$ and perirenal fat growth rate $(\mathrm{p}=0.0074)$ were reduced in RG2 compared to CG. In fetal perirenal BAT, the protein level of uncoupling protein $1(\mathrm{UCP} 1)(\mathrm{p}=0.0001)$ was lower in RG1 and RG2 compared with CG and UCP1 mRNA expression $(p=0.0265)$ was decreased in RG2. The protein level of myogenic factor 5 (Myf5) was also decreased in RG2 ( $\mathrm{p}=0.0001)$. In addition, mRNA expressions of $C y c l i n A$ $(\mathrm{p}=0.0109), \operatorname{Cyclin} B(\mathrm{p}=0.0019)$, CyclinD $(\mathrm{p}=0.0015)$, cyclin-dependent kinase 1 (CDK1) $(\mathrm{p}=0.0001)$, E2F transcription factor $1(E 2 F 1)(\mathrm{p}=0.0323)$, E2F4 $(\mathrm{p}=0.0101)$, and E2F5 ( $\mathrm{p}$ $=0.0018)$ were lower in RG1 and RG2. There were decreased protein expression of peroxisome proliferator-activated receptor- $\gamma(\operatorname{PPAR} \gamma)(\mathrm{p}=0.0043)$ and mRNA expression of CCAAT/ enhancer-binding protein- $\alpha(C / E B P \alpha)(\mathrm{p}=0.0307)$ in RG2 and decreased PPAR $\gamma$ mRNA expression $(\mathrm{p}=0.0008)$ and $\mathrm{C} / \mathrm{EBP} \alpha$ protein expression $(\mathrm{p}=0.0015)$ in both RG2 and RG1. Furthermore, mRNA expression of bone morphogenetic protein 4 (BMP4) $(\mathrm{p}=$ $0.0083)$ and $B M P 7(\mathrm{p}=0.0330)$ decreased in RG2 and peroxisome proliferator-activated receptor co-activator- $1 \alpha(P G C-1 \alpha)$ reduced in RG2 and RG1.

Conclusion: Our observations support that repression of regulatory factors promoting differentiation and development results in the inhibition of BAT maturation in fetal perirenal fat during late pregnancy with maternal undernutrition.

Keywords: Brown Preadipocytes; Growth and Development; Maternal Undernutrition; Ovine Perirenal Adipose Tissue

\section{INTRODUCTION}

Classical brown adipose tissue (BAT) depots present in the many mammalian fetuses and newborns including humans, sheep, and rodents; and located predominantly around the internal organs and in interscapular and supraclavicular regions [1,2]. In BAT, brown adipocytes contain many small lipid droplets and mitochondria that can uniquely produce large amounts of heat through the activation of non-shivering thermogenesis [3]. This type of thermogenic process is called uncoupled respiration and facilitated by the mediation of its key marker protein, the BAT-specific uncoupling protein uncoupling protein 1 (UCP1) [4,5], which is particularly important for neonatal animals and infants who have 
Table 1. Planes of maternal nutrition in three groups of ewes during late pregnancy

\begin{tabular}{lccc}
\hline Treatments & RG2 $^{\text {1) }}$ & RG1 $^{\text {1) }}$ & CG $^{\text {1) }}($ ad libitum) \\
\hline Mean daily hay intake $(\mathrm{g} / \mathrm{d})^{2)}$ & 440 & 843 & 1,689 \\
Mean daily crude protein intake $(\mathrm{g} / \mathrm{d})$ & 44 & 85 & 170 \\
Daily metabolizable energy intake $\left(\mathrm{MJ} \mathrm{ME} / \mathrm{kg} \mathrm{W}^{0.75} / \mathrm{d}\right)^{3)}$ & 0.18 & 0.33 & 0.67 \\
\hline
\end{tabular}

ME, metabolisable energy.

1) $R G 2$, restricted group 2; $R G 1$, restricted group 1; CG, control group.

${ }^{2)}$ Mean daily hay intake and crude protein intake are represented on a natural basis.

${ }^{3)}$ Daily metabolizable energy intake is represented on a dry matter basis.

greater demands on thermogenesis to adapt to the new extrauterine environment $[4,6,7]$. As the key window period for sheep fetal BAT development, the BAT growth primarily occurs in the perirenal region over the final third trimester of gestation $[8,9]$. The BAT cells life cycle starts with differentiation from the preadipocytes expressing Myf5 of embryonic mesoderm and includes a growth phase followed by growth arrest, clonal expansion, and terminal differentiation leading to mature BAT cells $[10,11]$. In contrast, white adipose tissues (WAT) are derived from the adipogenic lineage, and a white adipocyte contains a single, large lipid droplet for the storage of chemical energy as triglycerides [12]. The predominant type of fat is WAT in adult $[13,14]$.

Fetal undernutrition frequently occurs worldwide including animal agriculture [15]. The intrauterine fetal growth restriction of sheep caused by maternal undernutrition can cause serious decline in the survival rate and growth performance of lambs [16]. In addition, the mortality of newborn lambs caused by hypothermia has accounted for $25 \%$ to $35 \%$ of the total mortality rate of lambing period, and the number could reach more than $50 \%$ in some cases [17]. The appropriate prenatal BAT adipose tissue development is essential for adequate body temperature regulation at birth to ensure immediate survival [8]. The stunted development of BAT has been found in fetal sheep [18], which might be one of the important reasons for the increased mortality of neonatal animals due to their inability to maintain body temperature and resist cold. However, the mechanism underlying the inhibition of fetal BAT growth and development by maternal undernutrition during late pregnancy remains unknown. Therefore, the objective of this study was to investigate the effects of maternal undernutrition during late pregnancy on the regulatory factors of growth and development in ovine fetal perirenal BAT.

\section{MATERIALS AND METHODS}

\section{Animals and treatments}

All experimental procedures were conducted in conformity with institutional guidelines for the care and use of laboratory animals in China (The State Science and Technology Commission of China, 1988). This study was a companion study of a previous study whose details of animals, experimental design and procedures have been described [19]. In brief, eighteen second or third parity ewes were mated at synchronized estrus and had similar live weights (mean live weights $52.82 \pm 2.67 \mathrm{~kg}$ ) during the $\mathrm{d} 90$ of pregnancy. Pregnancies and singletons were confirmed by ultrasound scanning at approximately d 50 of gestation (Medison-SA-600, Shanghai, China). At the $\mathrm{d} 90$ of pregnancy, the Mongolian ewes were random allocated into three groups (Table 1): restricted group 2 (RG2, $0.18 \mathrm{MJ}$ metabolisable energy [ME]/ $\mathrm{kg}$ body weight $[\mathrm{BW}]^{0.75} / \mathrm{d}, \mathrm{n}=6$ ), restricted group 1 (RG1, $0.33 \mathrm{MJ} \mathrm{ME} / \mathrm{kg} \mathrm{BW}{ }^{0.75} / \mathrm{d}, \mathrm{n}=6$ ), and control group (CG, ad libitum, $0.67 \mathrm{MJ} \mathrm{ME} / \mathrm{kg} \mathrm{BW}^{0.75} / \mathrm{d}, \mathrm{n}=6$ ). All animals were housed in separate pens and fed with chopped hay (mainly Leymus chinensis, Table 2). Change for the experiment was conducted between 90 and 140 days of gestation, as the fetus gained $80 \%$ to $85 \%$ of its final birth weight during the last two months of pregnancy [20]. Animals were free to drink water and eat mineral mixtures (containing per kilogram: Ca, $15 \mathrm{~g}$; P, $11.5 \mathrm{~g} ; \mathrm{Mg}$ as $\mathrm{MgSO}_{4} \cdot 4 \mathrm{H}_{2} \mathrm{O}, 1 \mathrm{~g}$; $\mathrm{Fe}$ as $\mathrm{FeSO}_{4} \cdot 7 \mathrm{H}_{2} \mathrm{O}, 500 \mathrm{mg}$; $\mathrm{Cu}$ as $\mathrm{CuSO}_{4} \cdot 5 \mathrm{H}_{2} \mathrm{O}, 250 \mathrm{mg} ; \mathrm{Zn}$ as $\mathrm{ZnSO}_{4}, 175 \mathrm{mg}$; $\mathrm{Mn}$ as $\mathrm{MnSO}_{4}, 100 \mathrm{mg}$; $\mathrm{Co}$ as $\mathrm{CoC}_{12} \cdot 6 \mathrm{H}_{2} \mathrm{O}$, $20 \mathrm{mg}$; I as KI, $40 \mathrm{mg}$; Se as $\mathrm{Na}_{2} \mathrm{SeO}_{3} \cdot 5 \mathrm{H}_{2} \mathrm{O}, 1.5 \mathrm{mg}$; Yuan tong weiye Co., Ltd., Inner Mongolian, China). Ewes in the control group were fed at 08:30, 11:00, and 16:00 h per day (The Unconsumed feed accounted for approximately $10 \%$ of the total amount provided). The ewes in restricted groups were fed daily at 08:30 and 16:00 h. The unconsumed forage

Table 2. Composition of hay and refusals during the restriction period

\begin{tabular}{lcc}
\hline Items & Grass hay & Refusals \\
\hline $\mathrm{ME}(\mathrm{MJ} / \mathrm{kg})$ & 8.90 & - \\
$\mathrm{DM}(\%)$ & 88.42 & 91.99 \\
$\mathrm{CP}(\%)$ & 10.09 & 9.27 \\
EE (\%) & 4.34 & 2.72 \\
$\mathrm{NDF}(\%)$ & 71.98 & 71.19 \\
$\mathrm{ADF}(\%)$ & 35.82 & 36.60 \\
Ash (\%) & 4.67 & 4.39 \\
Ca (\%) & 0.57 & 0.68 \\
P (\%) & 0.09 & 0.08 \\
\hline
\end{tabular}

ME, metabolisable energy; DM, dry matter; $C P$, crude protein; $E E$, ether extract; NDF, neutraldetergent fiber; ADF, acid detergent fiber; Ca, calcium; $\mathrm{P}$, phosphorus. 
in control group was collected daily and recorded before feeding at 08:30 and sub-sampled for the ME and chemical analysis. The daily intake of hay offered for each group can be calculated by the ewe BW, nutrition value of hay and the energy plane. The formation is below:

$$
\mathrm{DI}=\left(\mathrm{L} \times \mathrm{W}^{0.75}\right) /(\mathrm{DM} \% \times \mathrm{ME})
$$

DI, daily intake; ME, measured metabolizable energy in hay; L, designed ME level in restricted groups.

\section{Tissue sample collection}

At 140 days of pregnancy, the fetuses were collected in from mothers. The body weight and the perirenal fat were measured in fetuses. Some samples of the perirenal fat tissues were snap-frozen in liquid nitrogen and kept at $-80^{\circ} \mathrm{C}$. Small pieces of the perirenal adipose tissue were fixed with paraformaldehyde $(0.1 \mathrm{~mol} / \mathrm{L}, \mathrm{pH}$ 7.4), embedded in paraffin, and cut into 4 to $6 \mu \mathrm{m}$ sections. Sections were stained with hematoxylin-eosin (H\&E) stain kit (D006, NJJCBIO, Nanjing, China) for microscopic examination.

\section{Immunohistochemistry}

To detect the expressions of peroxisome proliferator-activated receptor- $\gamma$ (PPAR $\gamma)$, CCAAT/enhancer-binding protein- $\alpha$ $(C / E B P \alpha)$, and UCP1 in perirenal fat, immunohistochemical staining was performed on $5 \mu \mathrm{m}$ thick tissue sections using rabbit polyclonal antibodies: PPAR $\gamma$ (bs4590R, BIOSS, Bengjing, China), C/EBP alpha (GTX100674, Gene Tex, Alton Pkwy, CA, USA), UCP1 (ab10983, Abcam, Waltham, MA, USA) as the first antibody in phosphate buffered salineTween. The secondary antibody was a horseradish peroxidase (HRP) (ab205718, Abcam, USA). Thermally induced antigen retrieval was performed by incubation with Tris-ethylene diamine tetraacetic acid for 20 minutes. Endogenous peroxidase was blocked by incubation with $3 \% \mathrm{H}_{2} \mathrm{O}_{2}$ for 10 minutes. Non-specific binding was blocked by incubating sections in normal goat serum for 2 hours at room temperature. Visualization was performed by incubation with HRP conjugated streptavidin followed by staining with diaminobenzidine substrate. Images were analyzed using a Leica microscope (Leica, DM750, Wetzlar, Germany) equipped with a ICC50 W camera (Leica) and Leica Application Suite software (version 4.6.2) at a magnification of $400 \times$. Image J (v1.45) software was used to determine the area of the positive signal divided by the total tissue area to calculate the area fraction of the positive signal.

\section{Immunoblotting and antibodies}

Total protein was extracted by lysing cells with RIPA lysate I (C5000050010; Sangon Biotech, Shanghai, China). Protein concentration was measured using a BCA Protein Assay Kit
(C5030210500; Sangon Biotech, China). Equal amounts of protein lysate were boiled for 5 minutes with $5 \times$ sodium dodecyl sulfate-polyacrylamide gel electrophoresis (SDS-PAGE) loading buffer (P1040; Solarbio, Beijing, China) and separated by SDS-PAGE Preparation kit (C631100; Sangon Biotech, China) and transferred to polyvinylidene fluoride membrane (Millipore ImmobilonTM P, Billerica, MA, USA). After blocking in 5\% skim milk dissolved in Trisbuffered saline $(0.02 \mathrm{M}$ Tris base, $0.14 \mathrm{M} \mathrm{NaCl}, \mathrm{pH} 7.4$ ) containing $0.1 \%$ Tween 20 , the membrane was incubated with primary antibodies overnight at $4^{\circ} \mathrm{C}$, and then with IRDye $800 \mathrm{CW}$ goat anti-rabbit immunoglobulin G (Li-COR Biotechnology, Lincoln, NE, USA) for 1 hour at room temperature. The primary antibodies used in this study were UCP1 (ab10983; Abcam, USA), myf5 (ab139523; Abcam, USA), PPAR $\gamma$ (bs4590R; Bioss, China), CEBPa (GTX100674; Gene Tex, USA), $\beta$-actin (bs0061R; Bioss, China) and glyceraldehyde-3-phosphate dehydrogenase (HC301; TransGen, Beijing, China). The blots were imaged by the Odyssey CLx Imaging System (Li-COR Biotechnology, USA) and the protein density analysis was performed using Image J (v1.45) software.

\section{Real-time polymerase chain reaction analysis}

Total RNA was isolated using RNAiso Plus reagent (9109; Takara, Shiga, Japan) according to the manufacturer's protocol. Reverse transcription of total RNA (500 ng) was performed using a PrimeScript RT reagent Kit (RR047B; Takara, Japan). Real-time reverse transcriptase (RT)-polymerase chain reaction (PCR) was performed using SYBR Premix Ex Taq (RR820A; Takara, Japan) in a LightCycler480 PCR system (Roche, Basel, Switzerland). The thermal cycling parameters were as follows: $95^{\circ} \mathrm{C}$ for $30 \mathrm{~s}$ for initial denaturation then 40 cycles of $95^{\circ} \mathrm{C}$ for $5 \mathrm{~s}, 60^{\circ} \mathrm{C}$ for $30 \mathrm{~s}$ and $72^{\circ} \mathrm{C}$ for $30 \mathrm{~s}$. Reactions were run in triplicate for each sample. Primer sequences used in RT-PCR of selected genes are provided in Table 3. The cDNA of perirenal adipose tissue was diluted with 10 times concentration gradient for RTPCR according to the above conditions and systems, and then the logarithm of template initial concentration was plotted with $\mathrm{Ct}$ to obtain the standard curve of each gene. At the same time, the amplification curve and dissolution curve of each gene in the process were recorded to judge the unity and integrity of the amplification product. The standard curve is controlled by amplification efficiency (Amplification efficiency $=10^{-1 / \text { slope }}$ ) and correlation coefficient. All samples were measured in triplicate, and the realtime PCR assay had similar efficiency and within the range of $90 \%$ to $110 \%$. Threshold cycle (Ct) was the value of PCR cycles at which the fluorescence signal of the PCR reaction reached a fixed threshold. For each sample, the Ct both for the target gene and endogenous control gene were determined to calculate $\Delta \mathrm{Ct}$ sample $\left(\mathrm{Ct}_{\text {target gene }}-\mathrm{Ct}_{\text {endogenous control }}\right)$. 
Table 3. The sequence of primers used in PCR analysis

\begin{tabular}{|c|c|c|c|}
\hline Gene & Primer sequence $\left(5^{\prime}-3^{\prime}\right)$ & Amplicon length (bp) & $\begin{array}{l}\text { Amplification } \\
\text { efficiency (\%) }\end{array}$ \\
\hline \multirow[t]{2}{*}{ Myf5 } & 5'- AGCAACCTGGATTGCCTCTC-3' & 78 & 99.7 \\
\hline & 5'- CTGGAGTTGCAGGCTGAGAA-3' & & \\
\hline \multirow[t]{2}{*}{ UCP1 } & 5'-CAACAGAAGGCTTGACGG-3' & 200 & 100.8 \\
\hline & 5'-CTGGCGAGGACAGAACC-3' & & \\
\hline Leptin & 5'-TGGCAGAATCCCACTCAC-3' & 335 & 95.3 \\
\hline PPARY & 5'- GTTGGTCGATGTCGCTGGAGATC-3' & & \\
\hline \multirow[t]{2}{*}{ C/EBPa } & 5'- ACAGCAACGAATACCGGGTG-3’ & 97 & 106.2 \\
\hline & 5'-TTCTGTTGCGTCTCCACGTT-3’ & & \\
\hline \multirow[t]{2}{*}{ PRDM16 } & 5'- CCGCCTCTGCTACCTCCTACG-3' & 136 & 96.8 \\
\hline & 5'- CTGTGGTGCTCTGGCTACTGTTG-3' & & \\
\hline \multirow[t]{2}{*}{ EBF2 } & 5'- GAAGGCTGGACCACTGGAGGAG-3' & 148 & 98.9 \\
\hline & 5'- GGATGTGCCGAGGAGGAGTCTG-3' & & \\
\hline \multirow[t]{2}{*}{ BMP4 } & 5'-ACCAGGCTACCAGGCGTTCTAC-3' & 81 & 95.3 \\
\hline & 5'-ATGGCGTGGTTGGTTGAGTTGAG-3' & & \\
\hline \multirow[t]{2}{*}{ BMP7 } & 5'-AGGCTATGCCGCCTACTACT-3' & 101 & 104.2 \\
\hline & 5'-TGAAGTGTACCAGCGTCTGC-3' & & \\
\hline \multirow[t]{2}{*}{ TGF $\beta$} & 5'- ACTACTACGCCAAGGAGGTCACC-3' & 140 & 98.3 \\
\hline & 5'- CACAGGTTCAGGCACTGCTTCC-3' & & \\
\hline \multirow[t]{2}{*}{ CyclinA } & 5'- ACCATGAGGACATTCACACGTACC-3' & 124 & 99.2 \\
\hline & 5'- ACTAACCAGTCCACGAGGATAGCC-3' & & \\
\hline CyclinB & 5'- GGAAATGTACCCTCCAGAAATCG-3’ & 232 & 105.5 \\
\hline \multirow[t]{2}{*}{ CDK2 } & 5'- ACAAGTTGACGGGAGAAGTG-3' & 235 & 97.9 \\
\hline & 5'- AGAGGAATGCCAGTGAGTGC-3' & & \\
\hline \multirow[t]{2}{*}{ CDK4 } & 5'- CAGTGGCTGAGATTGGTGTCG-3' & 148 & 102.5 \\
\hline & 5'- ACCTCCCGAACGGTGCTGAT-3' & & \\
\hline \multirow[t]{2}{*}{ E2F1 } & 5'- AGGTGCTGAAGGTGCAGAAACGG-3' & 283 & 98.2 \\
\hline & 5'- CGAAGGTCCTGGCAGGTCACATA-3' & & \\
\hline \multirow[t]{2}{*}{ E2F4 } & 5'- GGGTGCTAACAGGAAGAAATGGA-3' & 134 & 99.4 \\
\hline & 5'- GCAAATGGCTCTAAATGAGGGTAAAT-3' & & \\
\hline \multirow[t]{2}{*}{ E2F5 } & 5'- СТTСАСАТССАССААСССТССАС-3' & 199 & 102.3 \\
\hline & 5'- GAACAGTCTTGCGGCAGTAAACG-3' & & \\
\hline \multirow[t]{2}{*}{$\beta$-actin } & 5'-TCTTCCAGCCGTCCTTCCT-3' & 144 & 96.7 \\
\hline & 5'-TGCCAGGGTACATGGTGGT-3' & & \\
\hline
\end{tabular}

Myf5, myogenic factor 5; UCP1, uncoupling protein 1; PPARY, peroxisome proliferator-activated receptor- $\mathrm{C}$; $/ E B P a$, CCAAT/enhancer-binding protein-a; $P R D M 16$, positive regulatory domain-containing protein 16; $P G C$-1a, peroxisome proliferator-activated receptor co-activator-1a; KLF4, Krüppel-like factor 4; $E B F 2$, early B-cell factor 2; BMP4, bone morphogenetic protein 4; TGF $\beta$, transforming growth factor type- $\beta$; $C D K 1$, cyclin-dependent kinase 1; E2F1, E2F transcription factor 1.

In this study, the $\beta$-actin gene was used as an endogenous control. Subsequently, $\Delta \Delta \mathrm{Ct}\left(\Delta \mathrm{Ct}_{\text {sample }}-\Delta \mathrm{Ct}_{\mathrm{CG}}\right)$ was determined, and the relative expression was calculated by $2^{-\Delta \Delta C t}$.
For the CG group, the $\Delta \Delta \mathrm{Ct}$ is equal to 0 . Negative controls were performed in which cDNA was substituted by water. 


\section{Statistical analysis}

All data were analyzed by using the analysis of variance procedure as implemented in SAS 9.4 software. Duncan's test was used to identify significant differences between mean values. Significance was declared at $\mathrm{p} \leq 0.05$.

\section{RESULTS}

Fetal perirenal fat growth and structure

With the reduction of maternal feed intake, the fetal body weight was reduced in RG2 and RG1 ( $p=0.0069)$, and fetal perirenal fat weight $(\mathrm{p}=0.0077)$ and perirenal fat growth rate $(\mathrm{p}=0.0074)$ were decreased in RG2 group compared to CG group. For the ratio of perirenal fat to body weight, there were no differences between the restricted groups and the CG group ( $\mathrm{p}=0.0613$ ) (Table 4$)$. In the restricted groups, the number of WAT cells increased gradually with the decrease of the energy intake and the lipid droplets became larger, whereas BAT cells became sparse compared to control group from H\&E staining of sections of fetal perinatal adipose tissues. As the nutrient intake decreased, UCP1 protein level was significantly lower in the RG2 and RG1 compared with the control group $(\mathrm{p}=0.0001)$. The relative mRNA expression of UCP1 was decreased in the RG2 compared with CG and RG1 ( $p=0.0265)$. In addition, a decrease $(\mathrm{p}=0.0008)$ in the immunostaining of UCP1 was seen in RG2 and RG1 groups (Figure 1).

Myf5 expression in fetal perirenal brown adipose tissue Effects of feed restriction during late pregnancy on the gene expression of Myf5 in fetal perirenal BAT are shown in Figure 2. No significant difference was seen in mRNA expression of Myf5 in restricted groups $(\mathrm{p}=0.3100)$. However, the relative protein level of Myf5 were decreased in RG2 group compared with the CG group ( $\mathrm{p}=0.0001)$.

Expression of cell cycle regulatory factors in fetal perirenal brown adipose tissue

As show in Figure 3, the mRNA expressions of CyclinA ( $\mathrm{p}=$ 0.0109), CyclinB ( $\mathrm{p}=0.0019), C y c l i n D(\mathrm{p}=0.0015), C D K 1$ ( $\mathrm{p}$ $=0.0001), E 2 F 1(\mathrm{p}=0.0323), E 2 F 4(\mathrm{p}=0.0101)$, and E2F5 ( $\mathrm{p}$ $=0.0018)$ were lower in the RG2 and RG1 groups than those in the CG group, however, no differences were observed in expressions of cyclin-dependent kinase $2(C D K 2)(p=0.1608)$, CyclinE $(\mathrm{p}=0.2847)$, and cyclin-dependent kinase $4(C D K 4)$ $(\mathrm{p}=0.4074)$ among the fetal peripheral BAT of three groups.

\section{Expression of PPAR $\gamma$ and C/EBPa in fetal perirenal brown adipose tissue}

Figure 4 shows the effect of feed restriction during late pregnancy on the expression of PPAR $\gamma$ and C/EBPa in fetal peripheral adipose tissue. As the nutrient intake decreased, the relative mRNA expression of C/EBPa in the RG2 group was significantly lower than that of the CG group $(p=0.0307)$ and the relative protein levels were reduced in both restriction groups $(p=0.0015)$. Consistent with this, the reduced mRNA expression of PPAR $\gamma(\mathrm{p}=0.0008)$ was found in RG2 and RG1 groups, and the relative protein expression of PPAR $\gamma$ ( $p=0.0043$ ) was decreased in RG2 group compared to the CG group. Moreover, the decreased immunostaining of $\operatorname{PPAR} \gamma(\mathrm{p}=0.0341)$ and $\mathrm{C} / \mathrm{EBPa}(\mathrm{p}=0.0076)$ was seen in the RG2 and RG1 groups.

\section{Expression of others regulatory factors in fetal perirenal brown adipose tissue}

Effect of feed restriction during late pregnancy on the gene expression of others regulatory factors in fetal peripheral BAT is presented in Table 5. Expression of BMP4 $(\mathrm{p}=0.0083)$ and BMP7 ( $p=0.0330)$ mRNA decreased in RG2 group compared to CG group, but there was no difference found in the EBF2 gene expression ( $\mathrm{p}=0.6757)$. The mRNA expression of peroxisome proliferator-activated receptor co-activator-1a $(P G C-1 \alpha)$ reduced in both RG2 and RG1 groups $(\mathrm{p}=0.0104)$. Furthermore, there was no significant difference in the gene expression of positive regulatory domain-containing protein 16 (PRDM16) ( $\mathrm{p}=0.6146)$, krüppel-like factor $4(K L F 4)(\mathrm{p}$ $=0.4275)$, GATA binding protein $2($ GATA2 $)(\mathrm{p}=0.0897)$, and transforming growth factor type- $\beta(T G F \beta)(\mathrm{p}=0.1223)$ among those groups.

\section{DISCUSSION}

Adipose tissue is obviously limited by nutrition, and maternal changes can significantly change the development of fetal fat

Table 4. Effects of maternal undernutrition during late pregnancy on fetal body weight, the fetal perirenal fat weight

\begin{tabular}{|c|c|c|c|c|c|}
\hline Items & $\mathrm{CG}^{1)}(n=6)$ & $\mathrm{RG}^{1)}(\mathrm{n}=6)$ & $\operatorname{RG}^{1)}(n=6)$ & SEM & $p$-value \\
\hline BW (g) & $3,978^{a}$ & $3,573^{b}$ & $3,111^{c}$ & 111.00 & 0.0069 \\
\hline Perirenal fat weight $(\mathrm{g})$ & $11.57^{\mathrm{a}}$ & $10.17^{\mathrm{ab}}$ & $6.44^{b}$ & 1.340 & 0.0077 \\
\hline Perirenal fat index of BW (\%) & 0.29 & 0.28 & 0.20 & 0.0003 & 0.0613 \\
\hline Perirenal fat growth rate $(\mathrm{g} / \mathrm{d})$ & $0.21^{a}$ & $0.18^{\mathrm{a}}$ & $0.11^{b}$ & 0.0278 & 0.0074 \\
\hline
\end{tabular}

SEM, standard error of the mean; BW, body weight.

1) CG: control group, ad libitum, $0.67 \mathrm{MJ} \mathrm{ME} / \mathrm{kg} \mathrm{BW}^{0.75} / \mathrm{d}$; RG1: restricted group1, $0.33 \mathrm{MJ} \mathrm{ME} / \mathrm{kg} \mathrm{BW}^{0.75} / \mathrm{d}$; RG2: restricted group2, $0.18 \mathrm{MJ}$ ME/kg BWW.75/d.

${ }^{a-c}$ Means without a common superscript differ between CG, RG1, and RG2 $(p<0.05)$. 
(a)

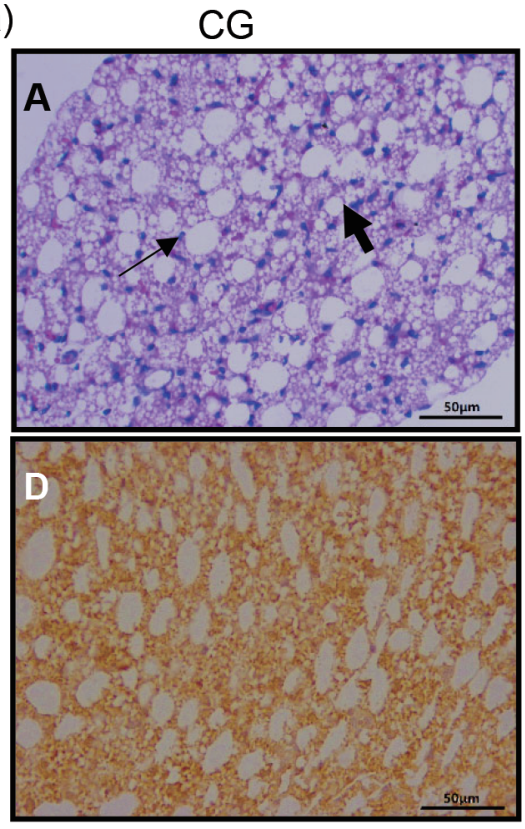

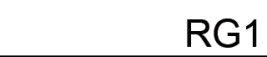
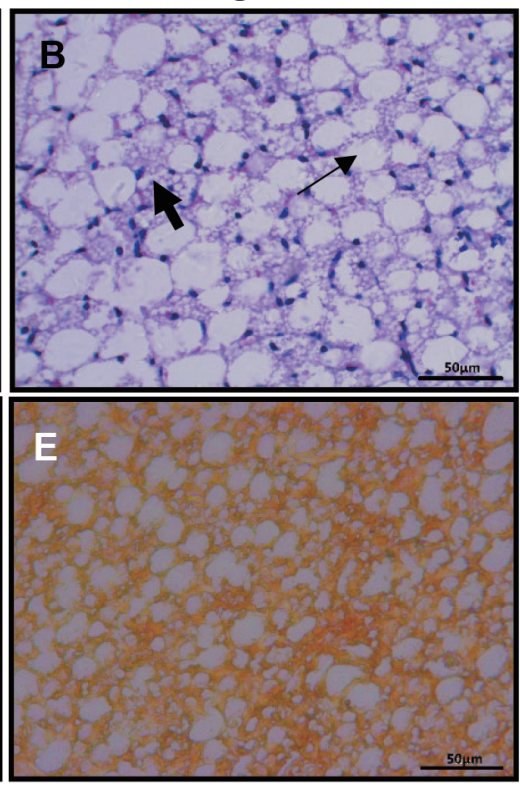
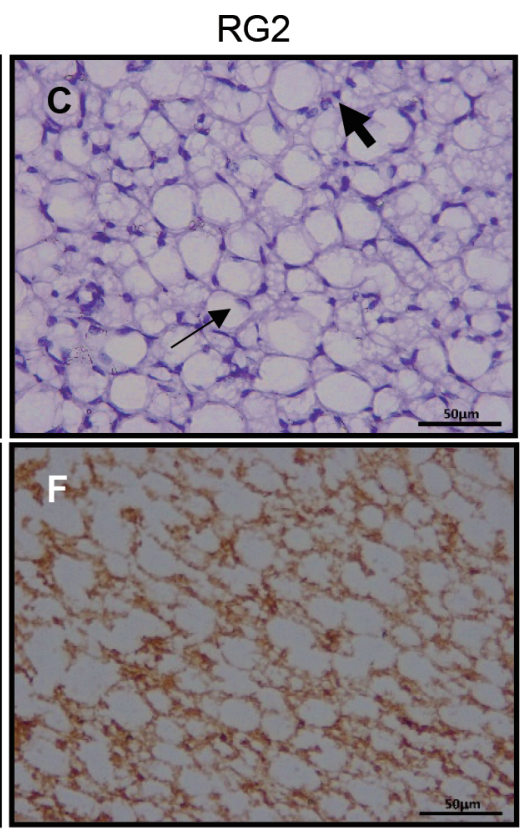

(b)

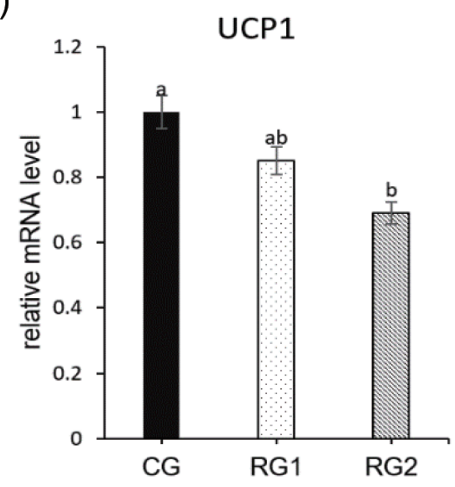

(c)

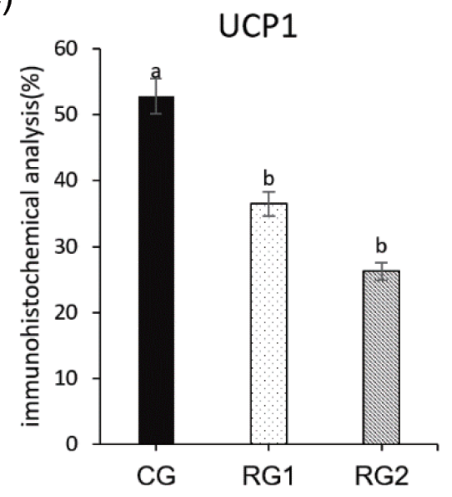

(d)

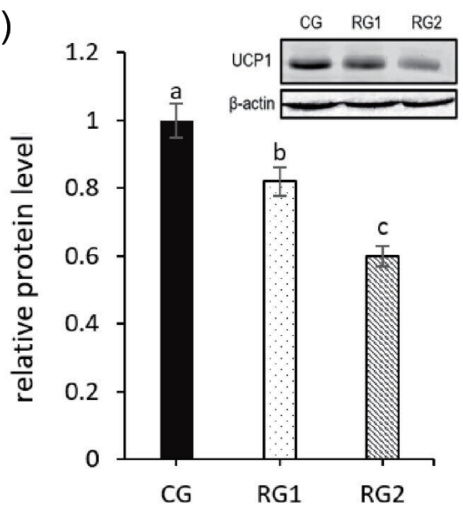

Figure 1. Effect of maternal undernutrition during late pregnancy on the histology and UCP1 expression of perinatal adipose tissue in ovine fetuses. (a) H\&E staining of sections of fetal perinatal adipose tissues (A-C the large and small arrows indicate brown adipose tissue and white adipose tissue, respectively $[\mathrm{bar}=50 \mu \mathrm{m}])$ and immunohistochemical staining of UCP1 expression in fetal perirenal BAT (D-F, bar $=50 \mu \mathrm{m})$. (b) relative mRNA level of UCP1. (c) quantitative data in immunohistochemical analysis of UCP1. (d) western blot of UCP1. UCP1 protein expression of all samples was expressed as fold changes, calculated relative to the CG group. ${ }^{a, b}$ Bars with different superscript differ ( $\left.p<0.05\right)$. UCP1, uncoupling protein 1; H\&E, hematoxylin and eosin.

[21]. In fetus, the adipocyte progenitor cell line of BAT is gradually transformed from mesenchymal stem cells (MSCs) through a complex series of differentiations [22]. Adipogenesis is the process of cell differentiation from preadipocytes to adipocytes, and the initial phase of BAT adipogenesis is characterized by the proliferation of Myf5 preadipocytes [11]. In addition, preadipocytes may be retained with the potential to develop into brown adipocytes even after brown adipocytes disappear [23]. During those processes, the cells expressing Myf5 are the direct preadipocytes of BAT although Myf5 is a myogenic regulator [24]. In this study, the Myf5 protein expression was significantly decreased in the RG2 group compared to the CG group, suggesting that the formation of the BAT adipocyte progenitor cell line in the RG2 group may be repressed by maternal under nutrition. Furthermore, the mRNA and protein expression of ovine fetal perirenal UCP1, a biomarker of BAT, was decreased in restricted groups, consistent with the reduced Myf5 protein in RG2 fetal perirenal BAT. The reduced Myf5 preadipocytes of BAT may be one of the important reasons that cause decreased maturation of fetal perirenal BAT and weight of perirenal BAT in the restricted groups.

Preadipocytes enter the cell cycle and experience a growth phase, until they eventually exit the cell cycle and acquire the features of mature BAT adipocytes [25]. The mature adipocytes don't have the ability to proliferate but with the ability for expansion, thus, the number of mature BAT adipocytes depends on the proliferation regulated by cell cycling of the 
(a)

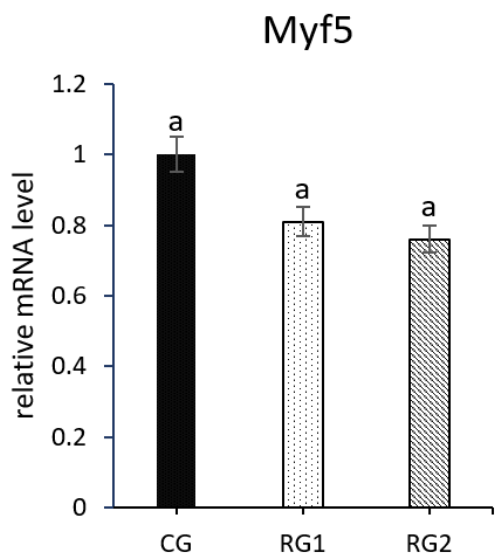

(b)

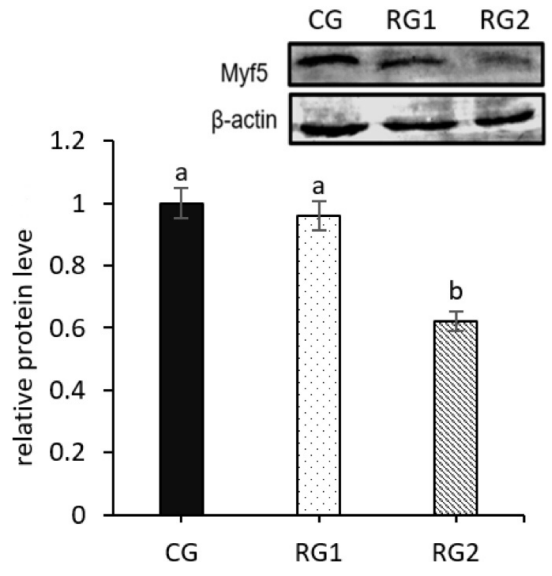

Figure 2. Effect of maternal undernutrition during late pregnancy on expression of Myf5 in fetal peripheral brown adipose tissue. (a) Relative mRNA level of Myf5. (b) Western blot of Myf5. Myf5 protein expression of all samples was expressed as fold changes, calculated relative to the CG group. ${ }^{a, b}$ Bars without a different superscript differ ( $\left.p<0.05\right)$. Myf5, myogenic factor 5 .

Myf5 preadipocytes [11]. The proliferation of preadipocytes regulates the completion of cell cycle through the joint action of cyclins and cyclin dependent kinases, which are vital regulators for the normal cell cycling [26]. CDK4 and CyclinD
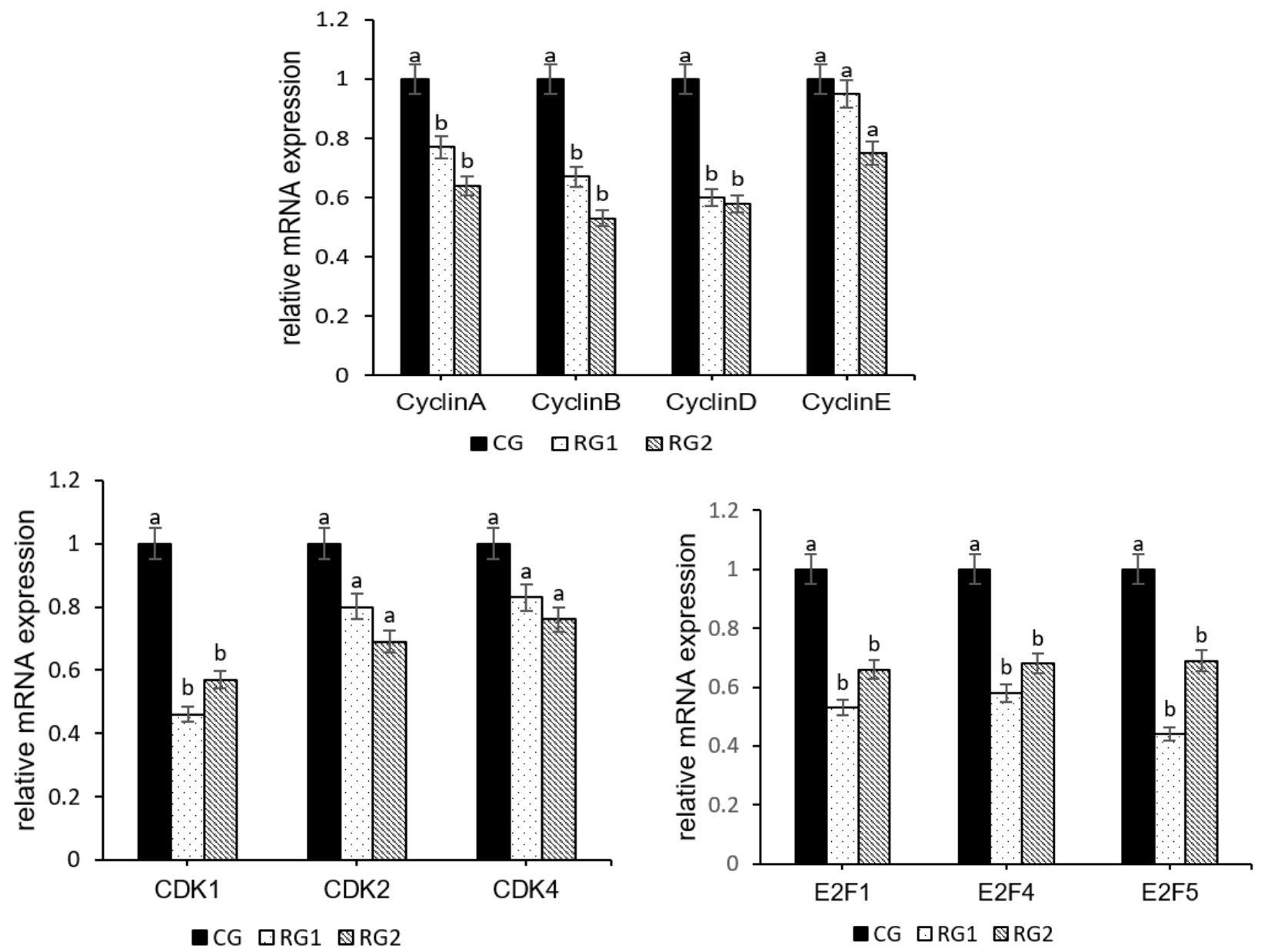

Figure 3. Effect of maternal undernutrition during late pregnancy on relative mRNA levels of cell cycle regulatory factors in fetal peripheral brown adipose tissue. ${ }^{a, b}$ Bars with different superscript differ $(p<0.05)$. 
(a)

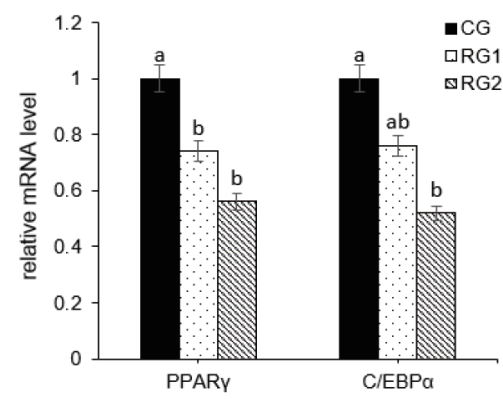

(d)

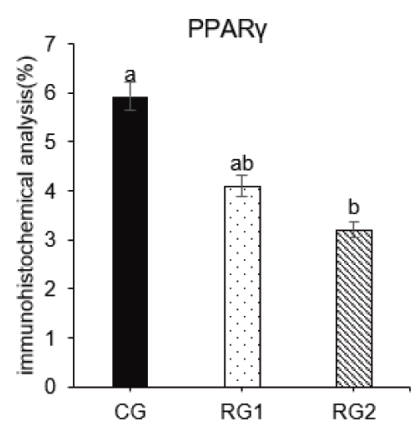

(b)

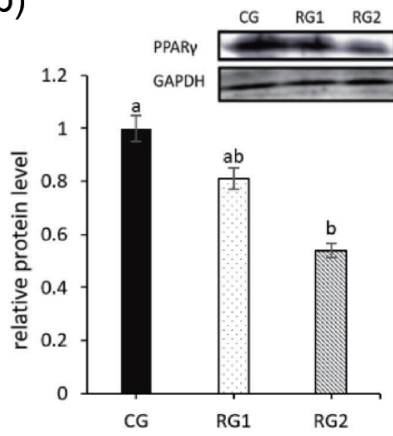

(c)

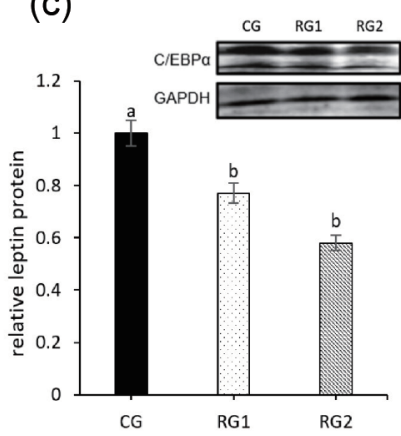

(e)
C/EBPa

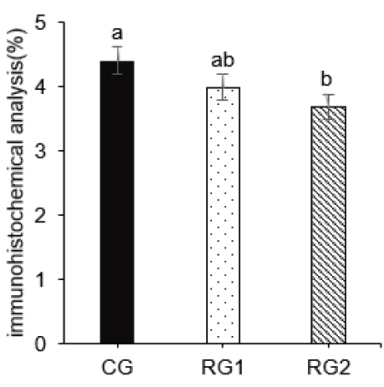

(f)

CG

RG1

RG2

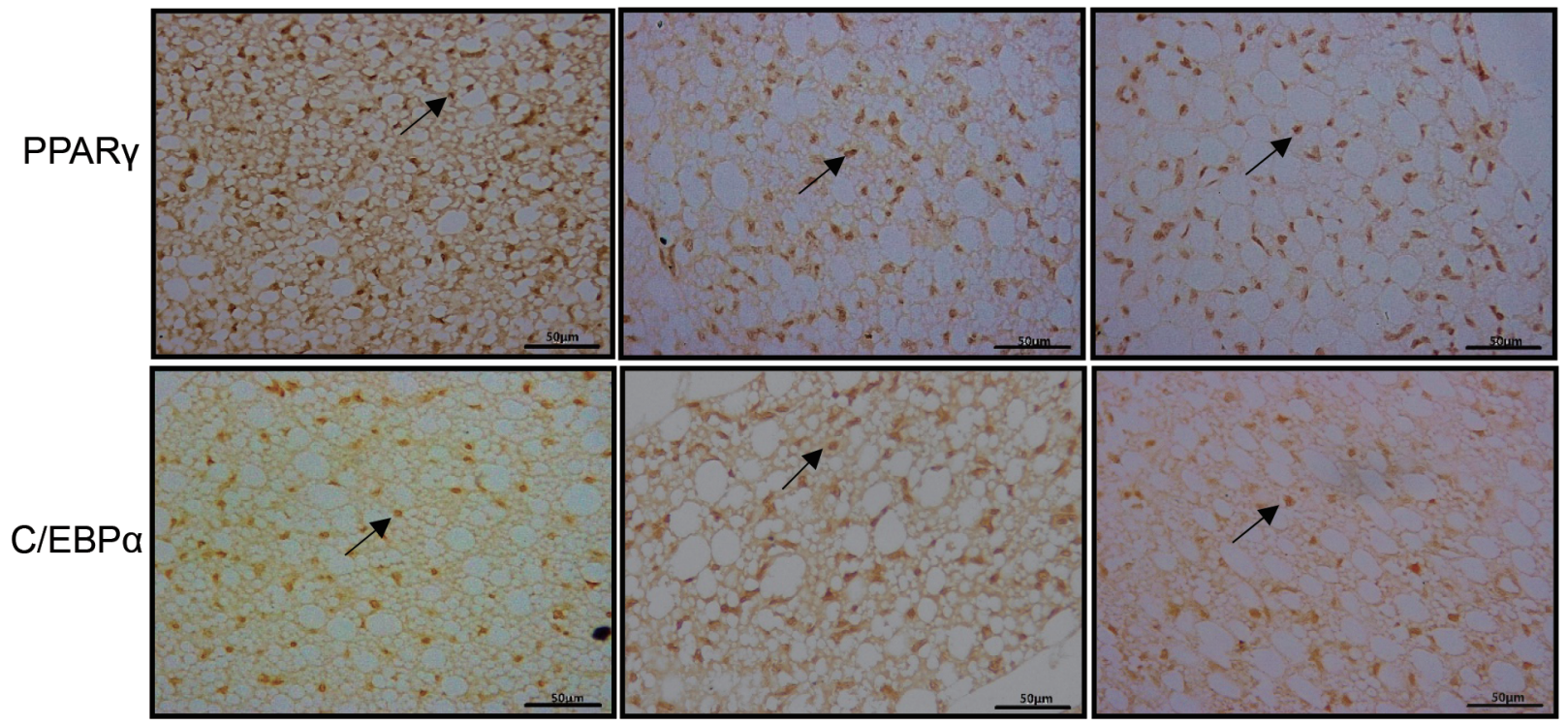

Figure 4. Effect of maternal undernutrition during late pregnancy on expression of PPARY and C/EBPa in fetal perirenal adipose tissue. (a) relative mRNA level of PPARY and C/EBPa. (b) Western blot of PPARY. (c) Western blot of C/EBPa. PPARY and C/EBPa protein expression of all samples were expressed as fold changes, calculated relative to the CG group. (d) quantitative data in immunohistochemical analysis of PPARy. (e) quantitative data in immunohistochemical analysis of C/EBPa. $(\mathrm{f})$ immunohistochemical staining of PPARY and C/EBPa expression in fetal perirenal BAT (bar $=50 \mu \mathrm{m}$ ), the arrows indicate the location of the nucleus expressing PPARY and CEBPa, to respectively. PPARy, peroxisome proliferator-activated receptor- $\gamma ; \mathrm{C} / \mathrm{EBPa}$, CCAAT/enhancer-binding protein-a; BAT, brown adipose tissue. ${ }^{\mathrm{a}, \mathrm{b}}$ Bars with a different superscript differ $(\mathrm{p}<0.05)$.

are responsible for getting cells out of quiescence (G0) and driving them through G1 [27]. The reduced gene expression of CyclinD and tended decrease in CDK4 seen in our study may indicate that the G1 phase development of BAT precursor cells was blocked. CDK2-CyclinA and CyclinE-CDK2 complexes are essential for completing $\mathrm{S}$ phase correctly [28], whereas CDK1-CyclinB is a vital regulator for normal withdrawal from mitosis [29]. In addition, E2Fs play roles that contribute to timely progression through G1/S phases [30]. The reduced gene expression of CDK1, CyclinB, E2F1, 
Table 5. Effect of maternal undernutrition during late pregnancy on expression of others regulatory factors in fetal perirenal brown adipose tissue

\begin{tabular}{|c|c|c|c|c|c|}
\hline Items & $\mathrm{CG}^{1)}(\mathrm{n}=6)$ & $\mathrm{RG}^{1)}(\mathrm{n}=6)$ & $\operatorname{RG}^{1)}(n=6)$ & SEM & p-value \\
\hline \multicolumn{6}{|c|}{ Adipose precursor cell development factor } \\
\hline EBF2 & 1.00 & 0.91 & 0.81 & 0.214 & 0.6757 \\
\hline BMP7 & $1.00^{\mathrm{a}}$ & $0.70^{\mathrm{ab}}$ & $0.56^{\mathrm{b}}$ & 0.097 & 0.0330 \\
\hline BMP4 & $1.00^{\mathrm{a}}$ & $0.89^{a}$ & $0.61^{b}$ & 0.104 & 0.0083 \\
\hline \multicolumn{6}{|c|}{ Differentiation promoting transcription factors } \\
\hline PRDM16 & 1.00 & 0.85 & 0.89 & 0.154 & 0.6146 \\
\hline \multicolumn{6}{|c|}{ Differentiation inhibiting transcription factors } \\
\hline GATA2 & 1.00 & 1.08 & 0.89 & 0.161 & 0.0897 \\
\hline TGF $\beta$ & 1.00 & 1.31 & 1.06 & 0.111 & 0.1223 \\
\hline
\end{tabular}

SEM, standard error of the mean; EBF2, early B-cell factor 2; BMP7/4, bone morphogenetic protein 7/4; PRDM16, positive regulatory domain-containing protein; PGC-1a, peroxisome proliferator-activated receptor co-activator-1a; KLF4, Krüppel-like factor 4; GATA2, GATA binding protein 2; TGF $\beta$, transforming growth factor type- $\beta$.

1) CG: control group, ad libitum, $0.67 \mathrm{MJ}$ ME/kg BW ${ }^{0.75} / \mathrm{d}$; RG1: restricted group 1, $0.33 \mathrm{MJ} \mathrm{ME} / \mathrm{kg} \mathrm{BW}^{0.75} / \mathrm{d}$; RG2: restricted group 2, $0.18 \mathrm{MJ}$ ME/kg BW0.75/d.

a,b Means without a common superscript differ among $C G, R G 1$, and $R G 2(p<0.05)$.

E2F4, and E2F5 in the restriction group in this study suggests that DNA synthesis and mitosis were inhibited during the proliferation of fetal perirenal BAT preadipocytes. Collectively, the inhibition of proliferation of preadipocytes in the present study may be directly attributed to variation of cell cycle regulators.

The BAT preadipocytes differentiate into mature adipocytes [31]. Adipogenic differentiation transcriptional cascades that mainly involve PPAR- $\gamma$ and the $\mathrm{C} / \mathrm{EBP} \alpha$ are considered the crucial determinants of adipocyte fate [32,33]. In our study, PPAR $\gamma$ mRNA expression and $\mathrm{C} / \mathrm{EBP} \alpha$ protein expression in perirenal fat were lower in the RG2 and RG1 groups compared with the control group, the PPAR $\gamma$ protein expression and $\mathrm{C} / \mathrm{EBP} \alpha \mathrm{mRNA}$ expression were decreased in RG2 fetuses. These decreases might also reduce preadipocyte development to mature BAT adipocytes and contribute to the decrease of perirenal fat mass. PPAR $\gamma$ gene expression was found to positively correlate to perirenal fat mass and birth weight [34]. While PPAR $\gamma$ and $\mathrm{C} / \mathrm{EBP} \alpha$ are well known essential transcriptional modulators of adipocyte development in all types of adipose tissue [35], EBF2, BMP7, BMP4, PRDM16, PGC-1 $\alpha$, KLF4, GATA2, and TGF $\beta$ also regulate adipogenesis [36]. As a pioneer factor in guiding and promoting the fate of BAT precursor cells in the process of MSCs differentiation into BAT potential precursor cells [37,38], the expression of EBF2 decreases with reduction of maternal nutrition, inhibits the development of BAT precursor cells, and reduces UCP1 expression [38]. BMP7 and BMP4 promote the acquisition of brown phenotype and regulate EBF2 activity [39]. BMP7 and BMP4 gene expressions were decreased in the RG2 group in this study, which may contribute to inhibition of the acquisition of BAT adipocyte phenotype in maternal malnutrition and hinder the normal differentiation of BAT preadipocytes in fetal perirenal fat. Meanwhile,
PPAR $\gamma$ and $\mathrm{C} / \mathrm{EBP} \alpha$ initiate positive feedback to induce their own expression and activate many target genes whose expression determines the BAT adipocyte [40]. PRDM16 stimulates the key characteristics of authentic brown adipocytes [41]. In addition, PGC-1 $\alpha$ plays a central role in BAT gene expression and coordinates the gene expression of key components of mitochondrial biogenesis in BAT [42]. KLF4 is required for promoted WAT differentiation, and its increase inhibits the development of BAT [14]. GATA2 expression blunts adipocyte differentiation through reduced PPAR $\gamma$ activity [43], whereas TGF- $\beta$ inhibits the production of adipose precursor cells which reduces the opportunity for the formation of mature BAT cells [44]. In this study, the gene expression of PGC-1 1 decreased in the restricted groups and PRDM16 showed a downward trend, while the KLF4 was increased, and no significant differences were found in GATA2 and TGF- $\beta$. These results indicate that inhibition of PPAR $\gamma$ and C/EBPa expression is associated with a decrease in the expression of other transcription target genes involved in adipogenesis in fetal perinephric BAT depot.

\section{CONCLUSION}

The reduction of BAT precursor cell cycle regulators causes the retardation of preadipocytes and followed by the decreased expression of BAT precursor cell development regulators including BMP4 and BMP7. Ultimately the expressions of PPAR $\gamma, \mathrm{C} / \mathrm{EBP} \alpha$, and PGC-1 $\alpha$ promoting differentiation were decreased which resulted in the inhibition of BAT maturation in fetal perirenal fat during late pregnancy with maternal undernutrition. These changes would be one of crucial potential-mechanisms hypothermia and high mortality of new born lambs. 


\section{CONFLICT OF INTEREST}

We certify that there is no conflict of interest with any financial organization regarding the material discussed in the manuscript.

\section{FUNDING}

This work was supported by National Natural Science Foundation of China (31760677, Beijing, China), Inner Mongolia Natural Science Foundation (2021MS03015, Hohhot, China) and Inner Mongolia Natural Science Foundation (2020MS 03042, Hohhot, China).

\section{ACKNOWLEDGMENTS}

We gratefully acknowledge Dr. Feng-Qi Zhao (Department of Animal and Veterinary Sciences, University of Vermont, Burlington) for help with the manuscript.

\section{REFERENCES}

1. Aherne W, Hull D. Brown adipose tissue and heat production in the newborn infant. J Pathol Bacteriol 1966;91:223-34. https://doi.org/10.1002/path.1700910126

2. Farmer SR. Molecular determinants of brown adipocyte formation and function. Genes Dev 2008;22:1269-75. https:// doi.org/10.1101/gad.1681308

3. Hansen JB, Kristiansen K. Regulatory circuits controlling white versus brown adipocyte differentiation. Biochem J 2006; 398:153-68. https://doi.org/10.1042/BJ20060402

4. Klingenberg M. Uncoupling protein-a useful energy dissipator. J Bioenerg Biomembr 1999;31:419-30. https://doi.org/10. 1023/a:1005440221914

5. Cannon B, Nedergaard J. Brown adipose tissue: function and physiological significance. Physiol Rev 2004;84:277-359. https://doi.org/10.1152/physrev.00015.2003

6. Kajimura S, Saito M. A new era in brown adipose tissue biology: molecular control of brown fat development and energy homeostasis. Annu Rev Physiol 2014;76:225-49. https:// doi.org/10.1146/annurev-physiol-021113-170252

7. Berry DC, Stenesen D, Zeve D, Graff JM. The developmental origins of adipose tissue. Development 2013;140:3939-49. https://doi.org/10.1242/dev.080549

8. Lukaszewski MA, Eberlé D, Vieau D, Breton C. Nutritional manipulations in the perinatal period program adipose tissue in offspring. Am J Physiol Endocrinol Metab 2013;305:e1195207. https://doi.org/10.1152/ajpendo.00231.2013

9. Wallacea JM, Milnea JS, Aitken RP, et al. Undernutrition and stage of gestation influence fetal adipose tissue gene expression. J Mol Endocrinol 2015;54:263-75. https://doi.org/10.1530/ JME-15-0048
10. Kajimura S, Seale P, Spiegelman BM. Transcriptional control of brown fat development. Cell Metab 2010;11:257-62. https:// doi.org/10.1016/j.cmet.2010.03.005

11.Park A, Kim WK, Bae KH. Distinction of white, beige and brown adipocytes derived from mesenchymal stem cells. World J Stem Cells 2014;6:33-42. https://doi.org/10.4252/ wjsc.v6.i1.33

12. Ali AT, Hochfeil WE, Myburgh R, Pepper MS. Adipocyte and adipogenesis. Eur J Cell Biol 2013;92:229-36. https:// doi.org/10.1016/j.ejcb.2013.06.001

13. Pope M, Budge H, Symonds ME. The developmental transition of ovine adipose tissue through early life. Acta Physiol 2014;210:20-30. https://doi.org/10.1111/apha.12053

14.Lefterova MI, Lazar MA. New developments in adipogenesis. Trends Endocrinol Metab 2009;20:107-14. https://doi.org/ 10.1016/j.tem.2008.11.005

15. Satterfield MC, Dunlap KA, Bazer FW, Wu G. Arginine nutrition and fetal brown adipose tissue development in nutrientrestricted sheep. Amino Acids 2013;45:489-99. https://doi. org/10.1007/s00726-011-1168-8

16. Nissen PM, Oksbjerg N. Quantification of prenatal effects on productivity in pigs. In: Greenwood PL, Bell AW, Vercoe PE, et al, editors. Managing the prenatal environment to enhance livestock productivity. New York, USA: Springer; 2010. pp. 37-70.

17.Xu YM. Death causes and countermeasures of newborn lambs in northern cold season. Zhongguo Dongwu Baojian 2013; 3:56-7.

18. Budge H, Dandrea J, Mostyn A, et al. Differential effects of fetal number and maternal nutrition in late gestation on prolactin receptor abundance and adipose tissue development in the neonatal lamb. Pediatr Res 2003;53:302-8.

19. Gao F, Liu YC, Zhang CZ, Zhang ZH, Song SS. Effect of intrauterine growth restriction during late pregnancy on the growth performance, blood components, immunity and anti-oxidation capability of ovine fetus. Livest Sci 2013;155: 435-41. https://doi.org/10.1016/j.livsci.2013.04.016

20.Symonds ME, Budge H, Stephenson T, McMillen IC. Fetal endocrinology and development--manipulation and adaptation to long-term nutritional and environmental challenges. Reproduction 2001;121:853-62. https://doi.org/10.1530/rep. 0.1210853

21.Symonds ME, Mostyn A, Pearce S, Budge H, Stephenson T. Endocrine and nutritional regulation of fetal adipose tissue development. J Endocrinol 2003;179:293-9. https://doi.org/ 10.1677/joe.0.1790293

22. Tang QQ, Lane MD. Adipogenesis: from stem cell to adipocyte. Annu Rev Biochem 2012;81:715-36. https://doi.org/10.1146/ annurev-biochem-052110-115718

23. Satterfield MC, Wu G. Brown adipose tissue growth and development: significance and nutritional regulation. Front Biosci (Landmark Ed), 2011;16:1589-608. https://doi.org/10. 
$2741 / 3807$

24. Lynes MD, Tseng YH. Unwiring the transcriptional heat circuit. PNAS 2014;111:14318-9. https://doi.org/10.1073/pnas.1416 145111

25. Otto TC, Lane MD. Adipose development: from stem cell to adipocyte. Cr Rev Biochem Mol Biol 2005;40:229-42. https:// doi.org/10.1080/10409230591008189

26.Johnson DG, Walker CL. Cyclins and cell cycle checkpoints. Annu Rev Pharmacol Toxicol 1999;39:295-312. https:/doi. org/10.1146/annurev.pharmtox.39.1.295

27. Barrièrea C, Santamaría D, Cerqueiraa A, et al. Mice thrive without Cdk4 and Cdk2. Mol Oncol 2007;1:72-83. https:// doi.org/10.1016/j.molonc.2007.03.001

28. Malumbres M, Barbacid M. Mammalian cyclin-dependent kinases. Trends Biochem Sci 2005;30:630-41. https://doi. org/10.1016/j.tibs.2005.09.005

29.Nigg EA. Mitotic kinases as regulators of cell division and its checkpoints. Nat Rev Mol Cell Biol 2001;2:21-32. https:// doi.org/10.1038/35048096

30. Calbo J, Parreno M, Sotillo E, et al. G1 Cyclin/cyclin-dependent kinase-coordinated phosphorylationof endogenous pocket proteins differentially regulates their interactions with E2F4 and E2F1 and gene expression. J Biol Chem 2002;277:5026374. https://doi.org/10.1074/jbc.M209181200

31.Lynes MD, Tseng YH. Deciphering adipose tissue heterogeneity. Ann NY Acad Sci 2018;1411:5-20. https://doi.org/ 10.1111/nyas. 13398

32. Rosen ED, MacDougald OA. Adipocyte differentiation from the inside out. Nat Rev Mol Cell Biol 2006;7:885-96. https:// doi.org/10.1038/nrm2066

33. Farmer SR. Transcriptional control of adipocyte formation. Cell Metab 2006;4:263-73. https://doi.org/10.1016/j.cmet. 2006.07.001

34. Duffield JA, Vuocolo T, Tellam R, et al. Intrauterine growth restriction and the sex specific programming of leptin and peroxisome proliferator-activated receptor gamma (PPARgamma) mRNA expression in visceral fat in the lamb. Pediatr Res
2009;66:59-65. https://doi.org/10.1203/PDR.0b013e3181a $7 \mathrm{c} 121$

35. Mota de Sá P, Richard AJ, Hang H, Stephens JM. Transcriptional regulation of adipogenesis. Compr Physiol 2017;7: 635-74. https://doi.org/10.1002/cphy.c160022

36. Seale P. Transcriptional regulatory circuits controlling brown fat development and activation. Diabetes 2015;64:2369-75. https://doi.org/10.2337/db15-0203

37. Wang W, Kissig M, Rajakumari S, et al. Ebf2 is a selective marker of brown and beige adipogenic precursor cells. Proc Natl Acad Sci USA 2014;111:14466-71. https://doi.org/10.1073/ pnas.1412685111

38. Rajakumari S, Wu J, Ishibashi J, et al. EBF2 Determines and maintains brown adipocyte identity. Cell Metab 2013;17: 562-74. https://doi.org/10.1016/j.cmet.2013.01.015

39. Elsen M, Raschke S, Tennagels N, et al. BMP4 and BMP7 induce the white-to-brown transition of primary human adipose stem cells. Am J Physiol Cell Physiol 2014;306:C43140. https://doi.org/10.1152/ajpcell.00290.2013

40. Harris RBS. Direct and indirect effects of leptin on adipocyte metabolism. Biochim Biophys Acta Mol Basis Dis 2014;1842: 414-23. https://doi.org/10.1016/j.bbadis.2013.05.009

41.Harms MJ, Ishibashi J, Wang W, et al. Prdm16 is required for the maintenance of brown adipocyte identity and function in adult mice. Cell Metab 2014;19:593-604. https://doi.org/10. 1016/j.cmet.2014.03.007

42. Cheng CF, Ku HC, Lin H. PGC-1 1 as a pivotal factor in lipid and metabolic regulation. Int J Mol Sci 2018;19:3447. https:// doi.org/10.3390/ijms19113447

43.Tong Q, Tsai J, Hotamisligil GS. GATA transcription factors and fat cell formation. Drug News Perspec 2003;16:585-8. https://doi.org/10.1358/dnp.2003.16.9.829340

44. Ignotz RA, Massague J. Type beta transforming growth factor controls the adipogenic differentiation of 3T3 fibroblasts. Proc Natl Acad Sci USA 1985;82:8530-4. https://doi.org/10. 1073/pnas.82.24.8530 